\title{
"WEST-EAST-WEST" - \\ LINE OF CONTINUITY IN THE DEVELOPMENT OF SCIENTIFIC KNOWLEDGE
}

Arzymatov J.S.

\begin{abstract}
АННОТАЦИЯ
В статье автор старается показать место и роль в развитии мировой науки выдающегося ученого средневековой Центральной Азии Абу Райхан Беруни. Изучение научного наследия Беруни показывает, что в его лице мы имеем ученого-естествоиспытателя и великого философа своего времени. Есть основания сделать вывод о том, что Беруни обеспечил один из моментов преемственной связи развития науки в форме триады.
\end{abstract}

In the article the author tries to show the place and role in the development of world science of the outstanding scientist of medieval Central Asia Abu Raikhan Beruni. The study of the scientific heritage of Beruni shows that in his person we have a natural scientist and a great philosopher of his time. There is reason to conclude that Beruni provided one of the moments of the continuity of the development of science in the form of a triad.

Ключевые слова: преемственность, закон отрицания отрицания, естественно научная картина мира, тезис, антитезис, синтез, геоцентрическая система мира, гелиоцентрическая система мира.

Key words: continuity, law of negation of negation, natural scientific picture of the world, thesis, antithesis, synthesis, geocentric system of the world, heliocentric system of the world.

Духовная культура средневековых народов Центральной Азии представляет одну из линий преемственного развития мировой культуры. С помощью духовного наследия средневековых восточных мыслителей христианский Запад познал древнегреческую науку и философию. Но роль и место средневековых мыслителей Востока в общественном прогрессе этим не ограничивается. Так как они не просто заимствовали и передали Западу древнегреческую философию и науку, а осуществили преемственную связь, поднимаясь на следующую ступеньку познания бытия. И неверно считать, что единственным источником их миропознания явилось только античное духовное наследие.

Особый вклад в развитии духовной культуры средневековой Центральной Азии внес его выдающейся представитель Абу Райхан Беруни (973-1048). Он известен нам своими выдающимися научными знаниями, передовыми социальнофилософскими идеями. Какой бы науки он ни коснулся, Беруни вносил в нее новое, иногда значение его взглядов понимали лишь несколько лет спустя. Многие мысли Беруни противоречили господствующим в тогдашней науке воззрениям и религиозным представлениям о мире. Поэтому его имя не было широко известно как имена великих современников вплоть до XIX века.

Систематическое изучение научного наследия ученого-энциклопедиста началось лишь со второй половины XIX века. Несмотря на это, духовное наследие Беруни и его современников до наших дней недооценивалось на должном уровне или подвергалось к искажению. Широкая масса людей знает их имена, но не знакома с их трудами. В литературе и учебниках, в которые у нас имеются, дается поверхностная информация об их творчестве и жизни. Правда, в некоторых источниках отмечается место в развитии науки таких ученых, как Ибн Сина, аль-Фараби и других. Но о высокой роли Беруни в развитии научного знания не отмечается. Несмотря на это, имя его можно ставить в один ряд с именами таких великих представителей мировой науки, как Птолемей, Леонардо да Винчи, Коперник, Ломоносов и др. $[8,4]$

В центре интересов Беруни лежало стремление к познанию природы и ее явлений, создание общей естественнонаучной картины мира. Поэтому он прежде всего естествоиспытатель. Но ученый придавал большое значение и общественным наукам. А сам Беруни считал себя, прежде всего, астрономом. Проблемам астрономии у него посвящено наибольшее количество трудов. И наиболее крупные заслуги перед наукой тоже связаны астрономией. В этой области он оставил настолько смелые мысли и догадки, что они нашли свое признание лишь несколько веков спустя.

Преемственность выступает как необходимое условие развития науки, ибо выражает факт все возрастающего приближения представлений человека к адекватному отражению объективного мира, все большего углубления познания человека. Преемственность в развитии научного познания осуществляется в нескольких формах. Одной из них является преемственность по форме триады.

В истории философии многие мыслители прошлого обращали внимание на троичный ритм 
как форму бытия и развития. Пифагорейцы считали, что лишь троица определяет целостность вещи. Триада занимала большое место в философии Канта, Фихте, Шеллинга и, особенно, Гегеля, для которого тройственность «скрывает в себе абсолютную форму, понятие»[2, 428] и является закономерностью саморазвития идеи.

Если применить эту форму к рассмотрению становления конкретных научных теорий, то здесь триадичная форма преемственности встречается довольно часто.

Птолемеевская геоцентрическая система мира в качестве своего оппонента имела гелиоцентрическую систему Арстарха Самоского. Хотя с точки зрения геоцентризма, формально возможна и гелиоцентрическая система мира, однако, последняя, по мнению последователей геоцентрической системы не обладала содержательными доказательствами своей правоты. Аргументация геоцентриков сводилась к следующей. «если бы Земля имела движение общее со всеми другими тяжелыми телами, то, очевидно, вследствие своей массы она определила бы эти тела, оставила бы всех животных, а равно и прочие тяжелые тела без всякой поддержки на воздухе, и наконец, скоро сама выпала бы из неба. Таковы последствия, к которым мы пришли: нелепее и смешнее нельзя себе и вообразить» $[3,98]$.

Как и многие современники, Беруни тоже в начале исходил из Птоломеевской системы строения мира, являвшимися в то время незыблемым и непререкаемым авторитетом, признанным мусульманской религией. В главе IX своего основного труда Беруни писал: «Земной шар находится в середине небесной сферы». Но в «Индии» Беруни излагает предположение относительно движения Земли, которые противоречили птоломеевской системе. Здесь он пишет о своих сомнениях в общепринятых воззрениях на устройство мира. «То, что Земля покоится,- а тоже одна из начальных истин астрономии, - относительно чего возникают трудно разрешимые сомнения»,- пишет Беруни в «Индии»[8, 254]. Этот вывод Беруни отражает смелость научного мышления, его стремление проникнуть в сущность явлений. Х.У. Садыкова в своей работе, посвященной творчестве Беруни сделал такой вывод: «Сначала он пришел к выводу, что геоцентрическая, и гелиоцентрическая система мира с одинаковым успехом могут служить для объяснения астрономических явлений, но позже он прочно встал на точку зрения гелиоцентризма» $[6$, 44]. Но многие ученые, которые исследовали Беруни, считают излишним это категорическое утверждение Садыкова, при этом они не видят в Беруни ученого предшествовавшего Копернику.

Известно, что до Беруни многие астрономы занимались этой проблемой. Даже сам Птолемей допускал, что можно считать небосвод неподвижным, а Земле приписать вращение с Запада на Восток. Однако Птоломей и многие другие ученые считали, что подобное утверждение нельзя принять за истинное, поскольку при вращении Земли находящиеся на ней предметы оказались бы отброшенными с нее. Впервые движение Земли с гелиоцентрическими идеями связал Гераклит. Лишь Арстарх Самосский принял допущение, что небо и Солнце неподвижны, Земля обращается по окружности, центром которой служит Солнце. Но его допущение не подвергался дальнейшему развитию.

Bce крупнейшие ученые-современники Беруни придерживались мнение об абсолютном покое Земли в центре мира. А Беруни, несмотря на это, и наперекор, утверждениям духовенства говорил о равноценности двух учений абсолютном покое Земли и о ее движении с точки зрения гелиоцентрического объяснения видимого движения небесных светил. И даже если он не делает выводов в пользу гелиоцентрической системы, большим его достижением было уже то, что в «Индии» он пишет о возможности вращения Земли и опровергает некоторые аргументы противников этого учения. Это само по себе подрывало учение Птоломея и явилось важной вехой в подготовке утверждения системы Коперника. Беруни снимает основное возражение, которое Птоломей выдвигал против возможности вращения Земли. Если Птоломей считал, что движение Земли вызвало бы отбрасывание всех вещей с ее поверхности в сторону, то Беруни снимает это возражение. Он говорит о тяготении, имеющемся между Землей и различными элементами, он полагал, что все элементы движутся к центру Земли.

В 1036-1037 аль-Беруни закончил свой главный труд Канон Масуда, посвященный общему описанию картина мира. Обосновывая шесть Птолемеевых принципов мироздания, в том числе принцип неподвижности Земли, аль-Беруни сделал ряд замечаний, свидетельствующих о допущении им, вслед за Ариабхатой (5 в.), движения Земли вокруг своей оси. Он рассмотрел гипотезу $o$ движении Земли вокруг Солние.

В «Каноне Масуда» Беруни поясняет причину, по которой он считает невозможным вращения Земли - огромная скорость вращения. Но его расчеты насчет скорости вращения Земли были близки к истинным величинам. Однако это нисколько не умаляет заслуги Беруни как предшественника Коперника, который подготавливал будущее торжество гелиоцентрической системы строения мира своими идеями о геометрической равноценности этих двух систем мира и тем, что снял некоторые возражения Птоломея и его сторонников. О том, какое большое значение имело решение этого вопроса в астрономии, но и в более широком плане, создавал и сам Беруни, который в «Индии» писал о том, что «это есть один из важнейших вопросов, который рассматривают только великие мужи»[8, 251]. Среди ученых более позднего времени разгорелось ожесточенная борьба вокруг вопроса о строении мира. Тем более поразительно предвидение Беруни, который в условиях всеобщего признания системы 
Птоломея, все же увидел ее слабые стороны, сделал большой шаг к гелиоцентрическим идеям.

Сущность преемственной связи в процессе познания по форме триады в следующем: противоречие между тезисом и антитезисом снимается и решается синтезом. Синтез включает в себя помирившихся тезис и антитезис. Если из примеров вычленить обще познавательную схему, отражающую триадичную форму преемственности, то она будет выглядеть так: движение познания от взглядов и концепций - Птолемеевская геоцентрическая система мира - $\mathrm{T}_{1}$ к взглядам и идеям аль-Беруни - $\mathrm{T}_{2}$, а от последних к $\mathrm{T}_{3}$ - теория Коперника, отрицающих $\mathrm{T}_{2}$ и одновременно воспроизводящих ряд идей $\mathrm{T}_{1}$. Преемственнопрогрессивное развитие научного познания элиминирует заблуждения, преодолевает их в более общих теориях и концепциях, сохраняя при этом положительные результаты предшествующих ступеней развития научного познания.

Изучение научного наследия Беруни, с точки зрения его мировоззрения, показывает, что в его лице мы имеем не только ученогоестествоиспытателя, но и выдающегося философа своего времени. Многие научные и философские труды ученого нам не известны. Научные труды и философские высказывания Беруни, которые дошли до нас, должны широко использоваться в изучении истории науки и философии.

Таким образом, есть основания утверждать, что наконец, объяснить и генезис гегелевской триады «тезис-антитезис-синтез», а сам закон получает необходимую интерпретацию. В действии закона отрицания отрицания обнаруживается важный момент формального или структурного характера: осуществляется преемственность во внутренней форме, в структуре, причем со ступенью еще более ранней, чем та, которая имелась до второго «отрицания».
Как мысленная модель, триада наиболее адекватна процессу познания, так как наглядно отображает относительную завершенность этого процесса на этапе синтеза.

Известный математик XIX века Эварист Галуа отметил: «Часто кажется, что одни и те же идеи родятся у нескольких, подобно откровению. Если поискать причину этого, то легко найти ее в трудах тех, которые им предшествовали, где представлены эти идеи без ведома их авторов»[7, 202]. Несмотря на то, что мы не имеем точных фактов о влиянии научного наследия Беруни на формирование взглядов европейских ученых эпохи Возрождений, есть основания сделать вывод о том, что Беруни обеспечил один из моментов преемственной связи синтетического развития науки.

\section{ЛИТЕРАТУРА:}

1.Антонов А.Н. Преемственность и возникновение нового знания в науке. Издатеьство Московского университета, 1985.

2.Гегель Г.В.Ф. Соч. М.; Л.: Госиздат, 1935. Т. XI. C. 428.

3.Гурев Г. Системы мира. - М., 1950. - С. 98.

4.Кирабаев Н.С. Социальная философия мусульманского Востока (эпоха средневековья) Москва, 1987.

5.Нысанбаев А.Н. Средневековой арабоязычный перипатетизм и исламская религиозная традиция. // Вопросы философии. 2002. - №3.

6.Садыков Х.У. Беруни и его работы по астрономии и математической географии. Москва, 1953.

7.Философия и методология науки. Под. Ред. В.И.Купцова. - Москва, 1996.

8.Шарипов А. Великий мыслитель Абу Райхан Беруни. - Ташкент, 1972. С. 4.

УДК (091)17

ГРНТИ 02

\title{
СЧАСТЬЕ КАК ДВОЙНОЙ ЖЕСТ ТРИГГЕРА: РАЗРЫВ И ЗАЧАТИЕ
}

\author{
DOI: $10.31618 /$ ESU.2413-9335.2021.1.87.1404 \\ Бильченко Евгеия Витальевна, \\ доктор культурологии, \\ профессор кафедры культурологии и философской антропологии \\ Национального педагогического университета, \\ 2. Киев, Украина \\ ведущий научный сотрудник отдела экранной культуры \\ Института культурологии Нацииональной академии наук Украины, \\ 2. Киев, Украина
}

\begin{abstract}
АННОТАЦИЯ
Цель исследования - экзистенциально-психологический анализ феномена счастья как состояния радикального разрыва с господствующими означающими символической гегемонии и одновременно добровольного ценностного заполнения образованного вакуума в символической структуре расколотого субъекта новыми смыслами, соответствующими его самости. Методы исследования: структурный психоанализ, постструктурализм семиотика культуры, герменевтика, философская компаративистика, деконструкция и универсальная этика, теологические методы корреляции светской и религиозной моделей мышления. Результаты исследования: сопоставление позитивной онтологии счастья в восточнославянской христианской классической мысли и негативной онтологии счастья в западном постлакановском постмодерне; осуществление синтеза образов счастья в путях мысли постмодерного Запада и модерного
\end{abstract}

